\title{
Mineral inclusions in diamonds from the Venetia kimberlites, Northern Province, South Africa
}

\author{
Viljoen, K.S. ${ }^{1}$, Phillips, D. ${ }^{1}$, Harris, J.W. ${ }^{2}$, and Robinson, D.N. ${ }^{1}$
}

1. Anglo American Research Laboratories (PTY) Ltd, P.O. Box 106, Crown Mines, 2025, South Africa

2. Department of Geology and Applied Geology, University of Glasgow, Glasgow G12 8QQ, United Kingdom.

This study identifies the mineralogy and determines the chemical compositions and equilibration conditions of representative syngentic inclusions in diamonds from the mined Venetia kimberlites.

The twelve kimberlites, all approximately 530 Ma old (Allsopp et al., 1995), are situated close to the borders with Botswana and Zimbabwe. They intrude into the Central Zone of the Limpopo Mobile Belt, which consists of three east-west trending zones of granulite-facies Archaean crust, $700 \mathrm{~km}$ in length and $250 \mathrm{~km}$ wide. wedged between two Archaean cratons: the Kaapvaal to the south and the Zimbabwean to the north.

The inclusion-bearing diamonds were selected from representative samples within four size ranges between $4.0 \mathrm{mms}(0.56 \mathrm{cts})$ and $1.3 \mathrm{~mm}(0.015 \mathrm{cts})$. Mineral inclusions identified were garnet, clinopyroxene (cpx), olivine, orthopyroxene (opx), chromite and sulphide, from the peridotitic paragenesis (P-type) and garnet, cpx and sulphide with rare kyanite, from the eclogitic growth environment (E-type). Coexisting mineral pairs such as P-type olivine+garnet and P- and E-type $\mathrm{cpx}+$ garnet permitted the determination of equilibration conditions for some of the diamonds.

Irrespective of paragenesis, sulphide inclusions were the commonest, with P-type suite diamonds generally being $90 \%$ more abundant than E-type diamonds. However, the proportion of E-type diamonds increased with increasing diamond size. On the basis of chemistry, a minor websteritic paragenesis (W-type) was identified. The mineral inclusion suites in Venetia Mine diamonds, therefore, fall predominantly into the typical worldwide pattern.

Mechanical crushing released the inclusions and individual minerals ranged in longest dimension from 70 to $400 \mu \mathrm{m}$. Many exhibited equant cubo-octahedral morphologies, indicating an imposed morphology by the enclosing diamond. Extracted minerals were mounted in brass stubs in epoxy resin and polished to a $1 \mu \mathrm{m}$ finish in preparation for microprobe analysis.

In terms of chemical compositions, the $\mathrm{CaO}$ versus $\mathrm{Cr}_{2} \mathrm{O}_{3}$ values for the P-type garnets (see Fig. 1), cover a wide range. from a very minor lherzolitic field, (to the right of the lherzolite trend), passing into a broad harzburgitic paragenesis, eventually with typical low $\mathrm{CaO}$ and high $\mathrm{Cr}_{2} \mathrm{O}_{3}$ values. Olivines and opx's are very magnesian, with typical $\mathrm{Mg} / \mathrm{Mg}+\mathrm{Fe}$ values of 0.94 to 0.95 , respectively. Fig. 1 also shows, however, that garnets with low chrome contents coexist with olivines and opx's with relatively low $\mathrm{Mg}$ \# numbers (0.91 and 0.92 respectively). Chromites have typical values in the range $64 \mathrm{wt} \%$ to $69 \mathrm{wt} \% \mathrm{Cr}_{2} \mathrm{O}_{3}$ there being no correlation with high chrome harzburgitic garnets (see Fig. 1). The three P-type cpx's have typical chemical compositions.

E-type garnets exhibit broad ranges in $\mathrm{FeO}$ (7.75 to 18.11 wt\%) and $\mathrm{CaO}$ (3.66 to 16.26 wt\%), with $\mathrm{TiO}_{2}$ and $\mathrm{Na}_{2} \mathrm{O}$ contents of up to $0.80 \mathrm{wt} \%$ and $0.24 \mathrm{wt} \%$, respectively (see Fig. 2). The cpx's of this paragenesis have very variable $\mathrm{Al}_{2} \mathrm{O}_{3}$ contents, ranging from $3.92 \mathrm{wt} \%$ to $20.76 \mathrm{wt} \%$, which is probably linked to the variable $\mathrm{Na}_{2} \mathrm{O}$ content $(2.24 \mathrm{wt} \%$ to $8.32 \mathrm{wt} \%$ ). The eight garnets from the W-type paragenesis are characterised by $\mathrm{Cr}_{2} \mathrm{O}_{3}$ contents in the range $0.07 \mathrm{wt} \%$ to $0.91 \mathrm{wt} \%$ and $\mathrm{CaO}$ contents of up to 4.85 wt \%. Seven W-type cpx's have $\mathrm{Al}_{2} \mathrm{O}_{3}$ and $\mathrm{Na}_{2} \mathrm{O}$ contents of up to 3.47 wt \% and 1.95 wt\% respectively. Mg \# numbers for the two W-type opx's are close to 80 .

For an assumed pressure of $50 \mathrm{kbar}$, calculated temperatures for 25 garnet-olivine pairs range from $922^{\circ} \mathrm{C}$ to $1362^{\circ} \mathrm{C}$ with a mean of $1152^{\circ} \mathrm{C}$. At $65 \mathrm{kbars}$ the values are $989^{\circ} \mathrm{C}$ to $1413^{\circ} \mathrm{C}$ with a mean 
of $1211^{\circ} \mathrm{C}$ (see Fig. 3). The one P-type garnet-cpx pair gave a temperature of $1247^{\circ} \mathrm{C}$ at $50 \mathrm{kbar}$. At the same pressure, the seven $\mathrm{W}$-type garnet-cpx pairs fall within the range $1167^{\circ} \mathrm{C}$ to $1247^{\circ} \mathrm{C}$. Two E-type mineral pairs, at $50 \mathrm{kbar}$, have equilibration temperatures of $1330^{\circ} \mathrm{C}$ and $1544^{\circ} \mathrm{C}$. With garnet-opx's, for which a pressure parameter can be determined, the data are constrained (see Fig. 3). The four P-type mineral pairs range in PT space between $59 \mathrm{kbar}$ and $69 \mathrm{kbars}$ and $1153^{\circ} \mathrm{C}$ and $1259^{\circ} \mathrm{C}$. With the two W-type inclusion pairs the data are between 55 and $62 \mathrm{kbar}$ and between 1189 and $1292^{\circ} \mathrm{C}$.

The chemical compositions and equilibration conditions of the inclusions in diamonds from the Venetia mine, suggests a crystallisation event in a thick, very depleted, highly magnesian peridotite mantle, which encloses minor eclogite and websterite veins or lenses.

\section{References}

Allsopp, H.L. Smith, C.B., Seggie, A.G., Skinner, E.M.W., and Colgan, E.A., 1995. The emplacement age and geochemical character of the Venetia kimberlite bodies, Limpopo Belt, Northern Transvaal. S. Afr. J. Geol., 98 (3), 239 - 244.

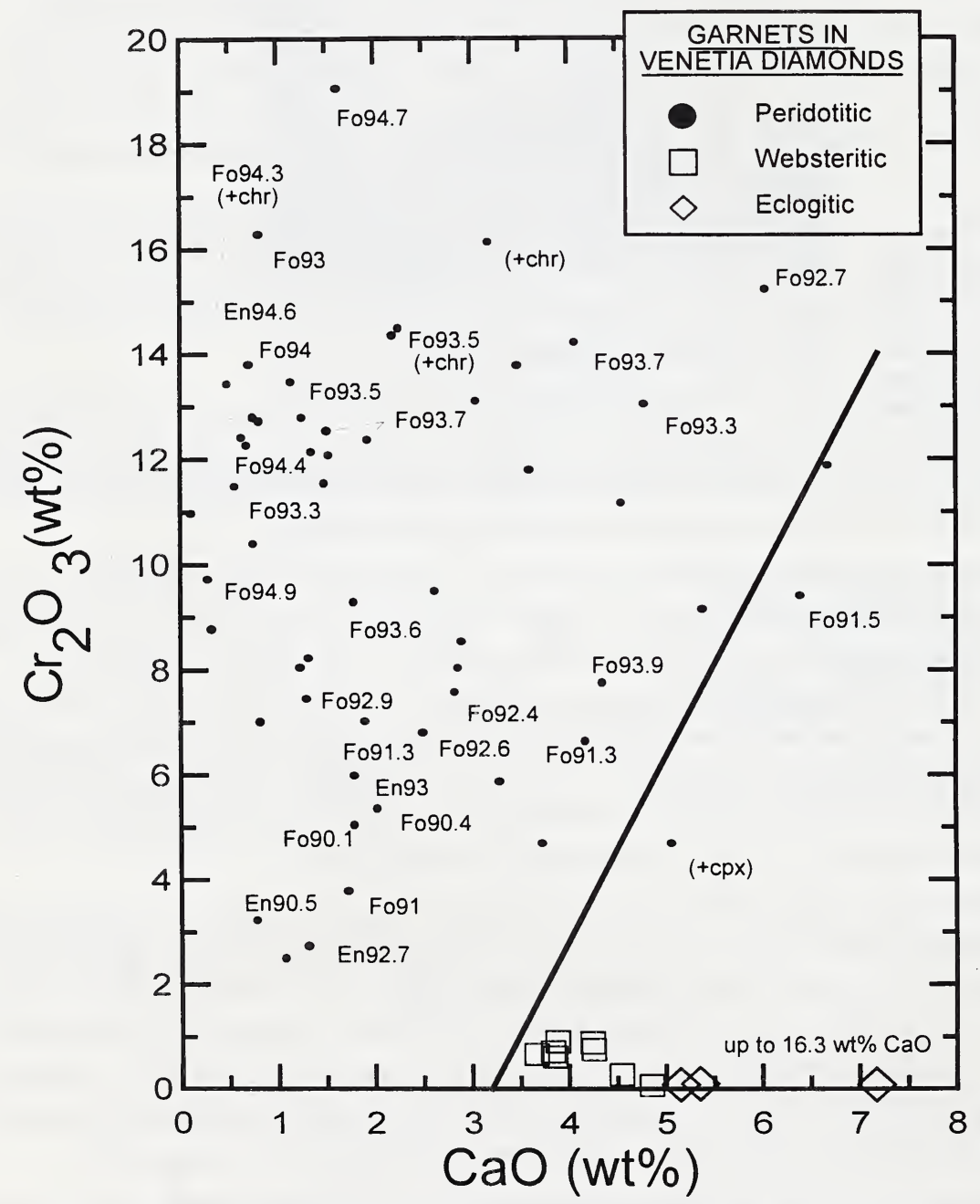

Figure 1. Plot of $\mathrm{CaO}$ against $\mathrm{Cr}_{2} \mathrm{O}_{3}$ for Venetia peridotitic, websteritic and eclogitic inclusions. $\mathrm{Mg} \#$ numbers for coexisting olivines and opx's are also presented. 


\section{$\mathrm{CaO}$}

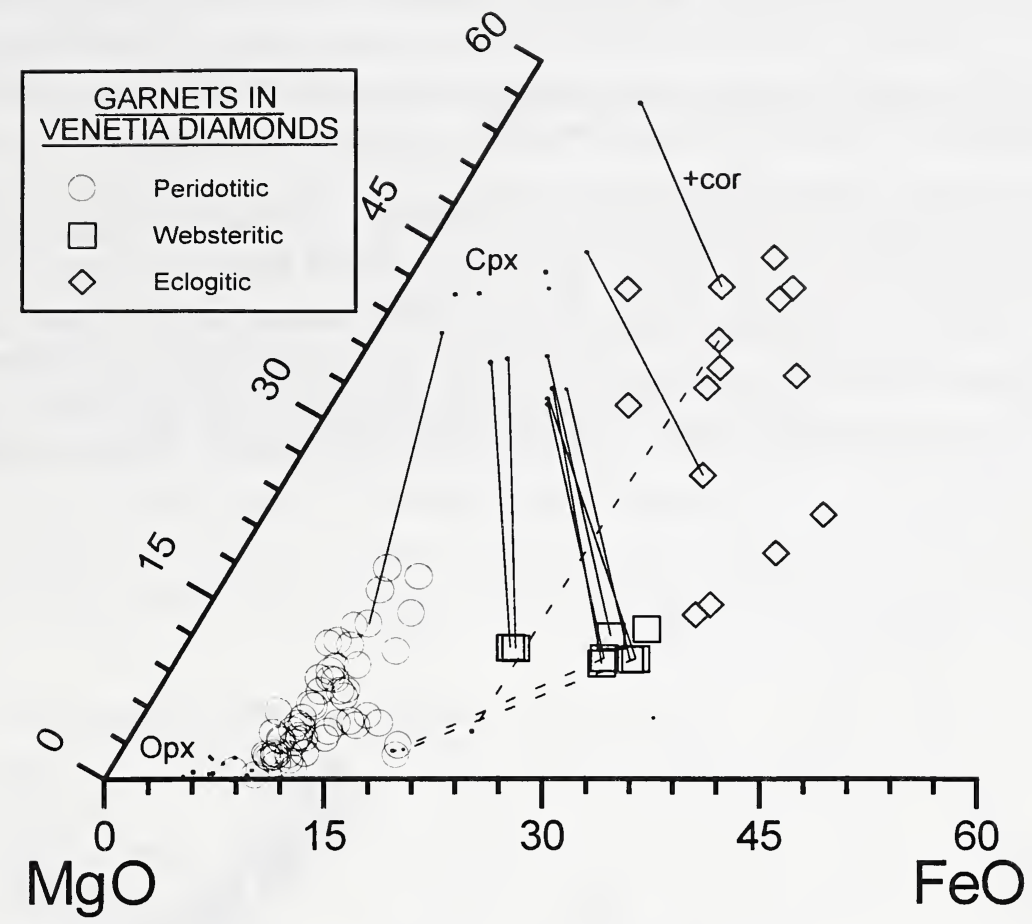

Figure 2. Ternary diagram for garnet, clinopyroxene and orthopyroxene in Venetia diamonds. Tielines join garnets with coexisting orthopyroxenes (dashed lines) and clinopyroxenes (solid lines).

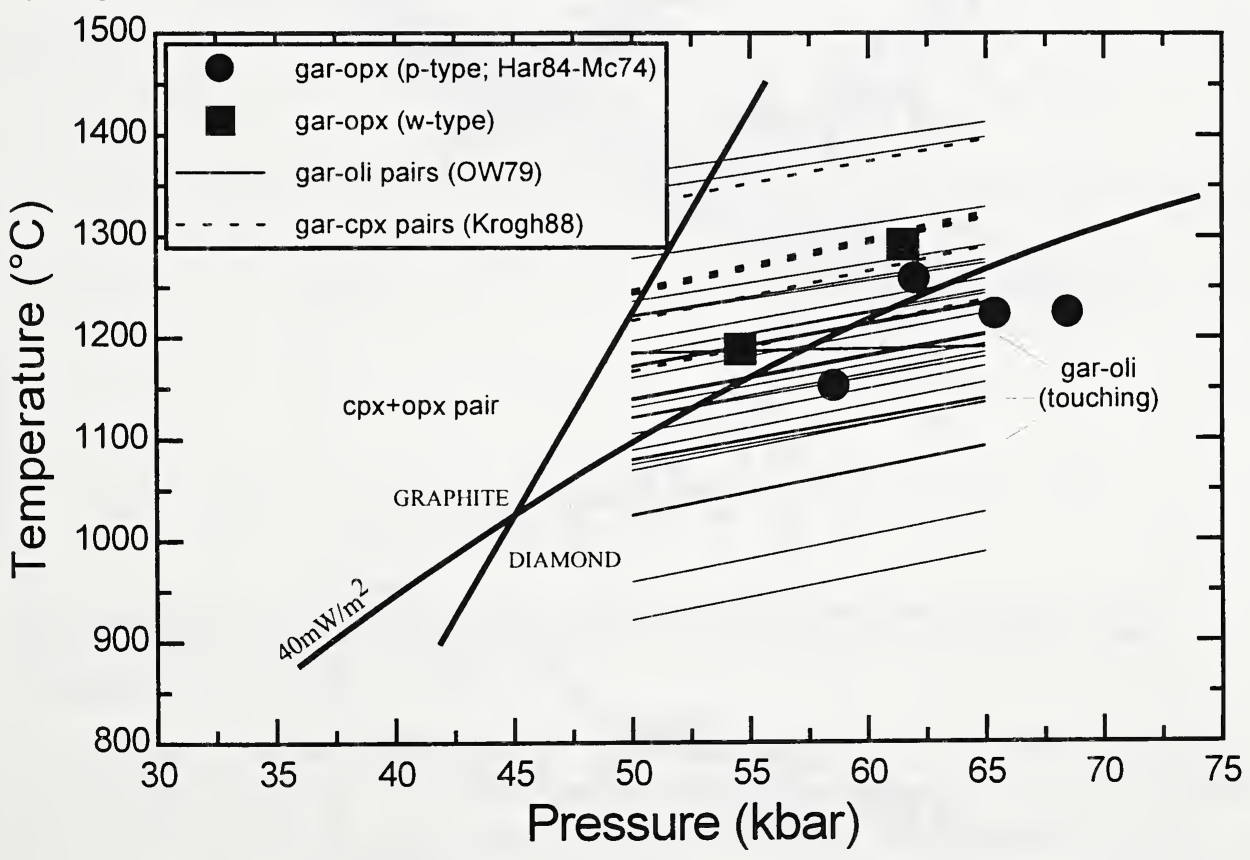

Figure 3. Equilibration conditions of Venetian inclusions in relation to a typical continental geotherm and the diamond-graphite stability curve. 